\title{
Study of the metallurgical bond between 316 steel substrates and NiCrAIY coating sprayed by HVOF and irradiated with a low power $\mathrm{CO}_{2}$ laser
}

\author{
Revestimentos de carboneto de tungstênio \\ (WC) depositados em aço 4340 por \\ irradiação com laser de $\mathrm{CO} 2$
}

Silvelene Alessandra Silva Dyer ${ }^{1}$, Renê Martins Volú ${ }^{1}$, Paulo Paiva Oliveira Leite Dyer ${ }^{2}$, Ana Claudia Costa Oliveira ${ }^{3}$, Getúlio de Vasconcelos ${ }^{1}$

\footnotetext{
${ }^{1}$ Laboratory of photonics - EFO - IEAv/DCTA, CEP: 12228-001 - 012-394-75441, São José dos Campos, São Paulo, Brasil.

${ }^{2}$ Laboratory of airport infrastructure engineering - EIA, ITA/DCTA, CEP: 12228-900, São José dos Campos, São Paulo, Brasil.

${ }^{3}$ Federal university of Pampa - UNIPAMPA, Alegrete, Rio Grande do Sul, Brasil.

e-mail: lenisoni@uol.com.br,rmvolu@gmail.com; pauldyer@ita.br; aclaudiacosta21@gmail.com, getulio@ieav.cta.br
}

\begin{abstract}
Coatings are used to promote the thermal protection of metal alloys. In the aeronautical industry, the coatings used to protect the turbine blades are called Thermal Barrier Coatings (TBC). The use of NiCrAlY is an alternative as a bonding layer in coatings for turbine blades and it is possible to increase its useful life. This work aims to study the metallurgical bond between the 316-stainless steel substrate and the NiCrAlY coating which was sprayed through the High-Velocity Oxygen-Fuel (HVOF) and after irradiated by a $\mathrm{CO}_{2}$ laser beam with power of $125 \mathrm{~W}$ and speed of $50 \mathrm{~mm} / \mathrm{s}$. The samples were characterized by scanning electron microscopy (SEM) and the semi-quantitative analysis energy dispersive spectroscopic (EDX) showed that the chemical composition of the coating and the substrate have maintained its original stoichiometry. The line scan analysis is a technique of the EDX to analyze the diffusion between the main chemical elements of 316 steel and $\mathrm{NiCrAlY}$ and $\mathrm{X}$-ray diffraction by identifying the alumina $\mathrm{AL}_{2} \mathrm{O}_{3}$ phases on the sample surface and the results showed the metallurgical bond between substrate and coating.
\end{abstract}

Keywords: HVOF, AISI 316 steel, coating, NiCrAlY, $\mathrm{CO}_{2}$ Laser.

\section{RESUMO}

Considerando a importância do desenvolvimento de novos materiais ao longo dos últimos anos; os pesquisadores vêm estudando soluções eficazes através do uso de revestimentos de alta dureza para aplicação em ferramentas de corte e matrizes de conformação. Revestimentos de carboneto de tungstênio (WC) são um dos mais utilizados em sistemas de geração de: energia, aeroespacial, automotivo e indústrias de transporte devido às suas propriedades, as quais, combinam alta dureza e resistência ao desgaste. O presente trabalho tem como objetivo verificar a melhoria das propriedades mecânicas do aço 4340 através da deposição de revestimento de WC pulverizado por pistola pneumática e posterior irradiação com laser de CO2. Os corpos de prova foram caracterizados por microscópio eletrônico de varredura, microscópio óptico e teste de microindentação (microdureza e medidas do módulo de elasticidade). Os resultados mostram que é possível obter revestimentos com alta dureza, sem poros e ligados metalurgicamente ao substrato.

Palavras-chave: Carboneto de tungstênio, CO2 Laser, alta dureza.

\section{INTRODUCTION}

Metallic coatings are effective and relatively inexpensive resources, which consists in modifying the proper- 
ties and characteristics of the surface of the alloys contributing to the enrichment of its properties, thus creating new materials that combine the properties of the substrate with the desirable characteristics of the surface $[1,2]$. In the aerospace and power generation industry, many of the equipment require excellent mechanical strength at high temperatures and in corrosive environments [3-6]. In recent years, one of the main applications that has received great importance and interest in the development are the ceramic and metallic coatings for the use as thermal and chemical barrier, respectively.

Blades are indispensable parts of the turbines also known as combustion engines. The turbines are made of three parts, consisting of: a compressor, a combustion chamber and the turbine, which consists of a rotor with fixed and fixed vanes whose purpose is to capture and convert mechanical and thermal energy contained in a working fluid. The blades are located after the combustion chamber, which region surrounds an oxidizing atmosphere, and the pressure and the temperature that can reach 50 bar and $1500{ }^{\circ} \mathrm{C}$ [7], respectively.

The coatings used on the turbine blades are known as Thermal Barrier Coating (TBC), whose main characteristics are high melting point, high corrosion and oxidation resistance at high temperatures [8]. The thermal barrier coating has two functions to thermal and chemical protection during the turbine operating cycles. The TBC coating consists of: A Bond Coat (BC), a Thermo-Grown Oxide layer (TGO) that promotes chemical protection to the substrate and a Ceramic Coat (CC) that protects thermally the system $[9,10]$.

The TBC's consist of coatings containing Chromium $(\mathrm{Cr})$, Aluminum (Al) [8], a rare earth element, such as Yttrium (Y). From its basic composition comes its generic name MCrAlY, where element $\mathrm{M}$ can be nickel $(\mathrm{Ni})$, Cobalt $(\mathrm{Co})$ and iron $(\mathrm{Fe})$ or the mixture between these elements. The bonding coating that has been most applied to components working in corrosive environments of high temperatures is NiCrAlY. The amount of aluminum should be appreciable, serving as a reservoir for the formation of the oxide layer on the surface of the coating during the operation. In order to maintain fatigue resistance, the aluminum and chromium concentrations should be kept in low values because high levels will reduce the ductility of the coating [11].

High Velocity Oxygen-Fuel (HVOF) is one of the most used coating deposition techniques. It is a process that consists of the deposition of metallic materials and cobalt-based alloys (in a fused condition) on a substrate forming a coating with special characteristics. In this process, the fuel gas is burned with oxygen in a high-pressure combustion chamber generating a high-speed exhaust jet [12]. The material is introduced into the nozzle, it is heated and then it is accelerated to the target. The sputtered particles adhere to the substrate by mechanisms of mechanical, chemical-metallurgical and physical nature, depending on the temperature of the heat source and velocity imposed on the particles, which by the overlap form layers of lamellar structure with oxides and pores. The technical literature indicates particle velocities of 550.00 to $1200.00 \mathrm{~m} / \mathrm{s}$ [13].

A viable alternative process to decrease the pores of the HVOF process and to obtain a dense anchoring of the coatings is the use of a laser to heat and treat the surface [14]. This process allows, by the absorption of beam radiation and then by their rapid cooling, a coating with better characteristics than those obtained using only the HVOF process. The high energies available in the laser process can favor the formation of metallurgical bond between the coating and substrate and contribute to better anchor it to the substrate, avoiding the detachment of the coating. This method allows the development of coatings with porosity control, being possible to close the pores or densify the coating on the surface to avoid the diffusion of oxygen and prevent the oxidation of the substrate $[15,16]$.

\section{MATERIALS AND METHODS}

The High Velocity Oxygen Fuel method (HVOF) showed at the Figure 1 was used to deposit the NiCrAlY powder coating on the 316-stainless steel substrate. In this process, the fuel is burned with oxygen at high pressure in a combustion chamber generating a high-speed exhaust jet. The material to be deposited in powder form is introduced into the flame, being heated and designed against a substrate, according to the Figure 1. 


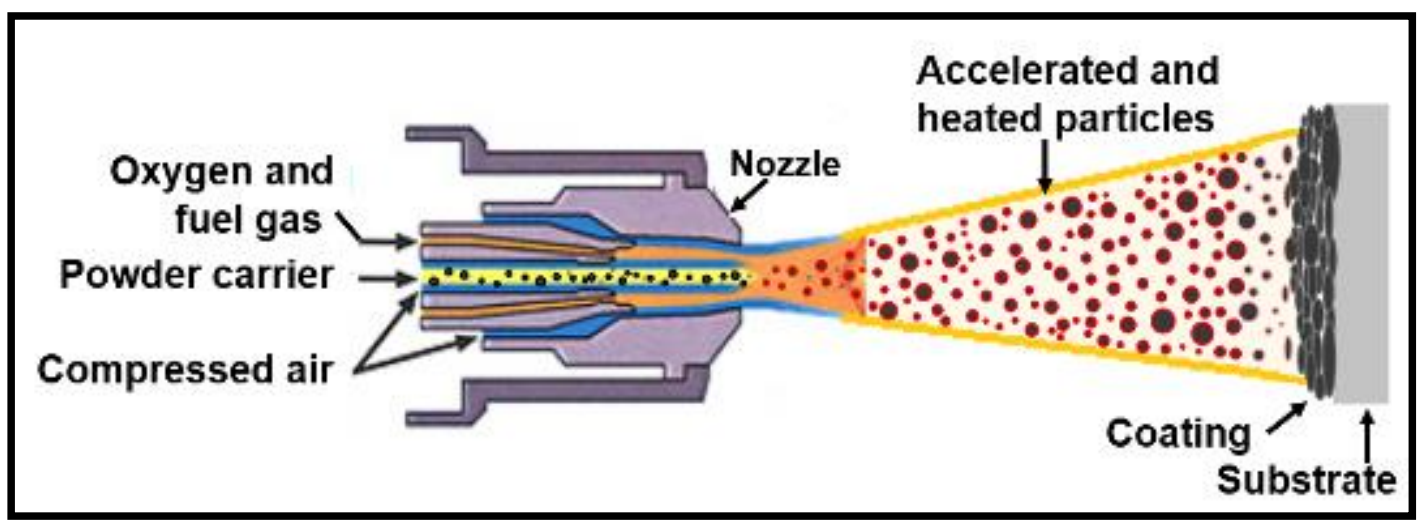

Figure 1: Scheme of the HVOF deposition process.

The coating deposited by the HVOF, which parameters deposition are shown in the Table 1, had an average thickness of $100.00 \mu \mathrm{m}$.

Table 1: The parameters of equipment conditions for HVOF deposition.

\begin{tabular}{l|l|l}
\hline EQUIPMENT CONDITIONS & PARAMETERS & UNIT \\
\hline Feed rate & 76.00 & $\mathrm{~g} / \mathrm{min}$ \\
\hline Oxygen pressure & $140.00+/-5.00$ & $\mathrm{psi}$ \\
\hline Fuel pressure & $133.00+/-5.00$ & $\mathrm{psi}$ \\
\hline Nitrogen pressure & 50.00 & $\mathrm{psi}$ \\
\hline Air compressed pressure & 116.00 & $\mathrm{psi}$ \\
\hline
\end{tabular}

After the deposited layer of $\mathrm{NiCrAlY}$, the samples were irradiated by a $\mathrm{CO}_{2}$ laser beam with power of $125.00 \mathrm{~W}$ and wavelength of $10.60 \mathrm{~m}$. The scanning speed was maintained in $50.00 \mathrm{~mm} / \mathrm{s}$. The purpose of the laser treatment is to generate a metallurgical bond between the substrate and the coating and, consequently: increases the adhesion of the coating, promotes a gradual change of coefficient of thermal expansion at the metal/NiCrAlY interface and prevents the occurrence of delamination coating failures.

The sample irradiated with the $\mathrm{CO}_{2}$ laser where was cross-section evaluated using a, metallographic preparation of sample, consisting in: sanding, polishing and chemical etching with Nital acid. The sample characterizing was done by Scanning Electron Microscopy (SEM), by energy dispersive spectroscopic (EDX) to obtain the semi-quantitative analysis and by line scan-EDX technique line analysis to verify the diffusion of the elements of the substrate and coating and by X-ray diffraction for identifying the growth of aluminum oxide $\left(\mathrm{Al}_{2} \mathrm{O}_{3}\right)$.

\section{RESULTS AND DISCUSSION}

The Table 2 shows the chemical composition of the 316-stainless steel used as substrate. This steel was chosen (steel AISI 316) as the substrate because it contained high levels of chromium (17\%).

Table 2: Chemical Composition of 316 Stainless Steel.

\begin{tabular}{l|l|l|l|l|l|l|l}
\hline CHEMICAL ELEMENT & Cr & N & Mo & C & Si & S & P \\
\hline Weight $(\%)$ & 17.0 & 12.0 & 2.5 & 0.08 & 0.07 & 0.030 & 0.045 \\
\hline
\end{tabular}

The Figure 2 (a) shows the NiCrAlY powder where it is possible to view that the particles are rounded in shape and their chemical composition is about $31.00 \% \mathrm{Cr}, 11.30 \% \mathrm{Al}, 0.70 \% \mathrm{Y}$ and the remainder Ni. The Figure 2 (b) shows the microstructure of the NiCrAlY coated sample applied by the HVOF process, with a microstructure obtained by SEM of the fractured sample with NiCrAlY coating, applied by HVOF. It can be observed that the surface is irregular, and the microstructure consists of porous lamellae. Spraying by HVOF involves a continuous and rapid deposition of the material, where the solidification of molten or semi- 
charged droplets generally occurs. This process results in flat and imperfect microstructures with porosity. The thickness of the coating measured was of the order of $100.00 \mu \mathrm{m}$.

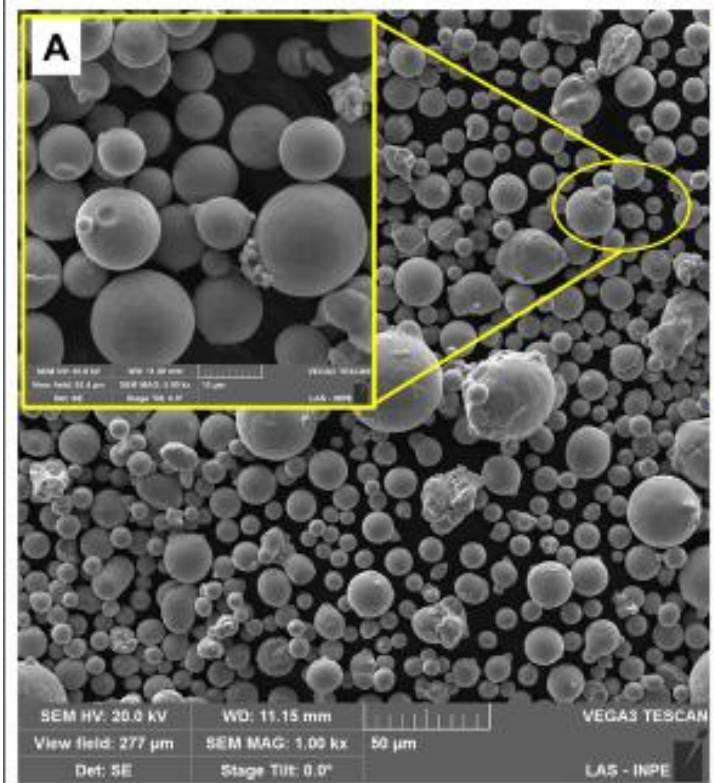

(a)

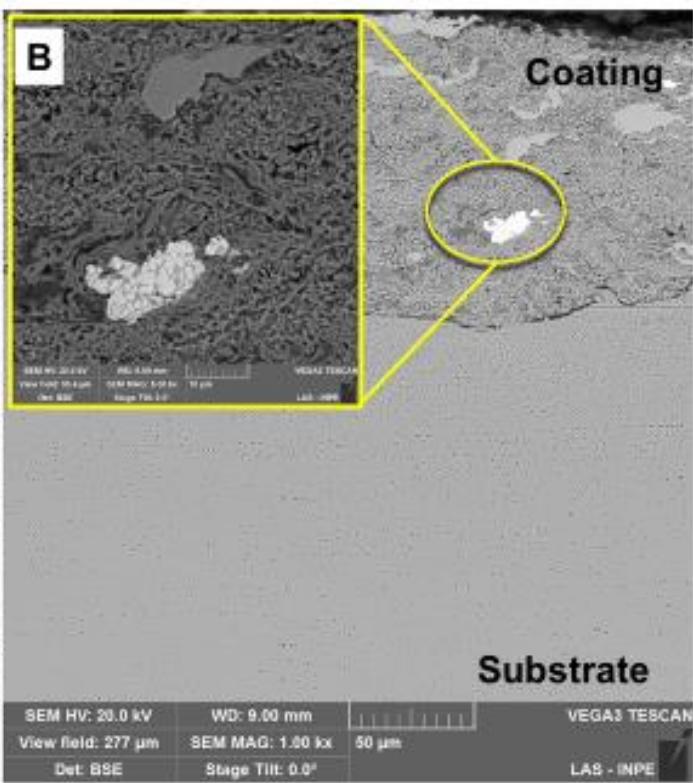

(b)

Figure 2: SEM micrographies: a) Morphologies of the NiCrAlY particles and (b) Cross-section of the NiCrAlY coating on 316 steel deposited by HVOF.

The Figure 3 shows a SEM micrograph of the fractured sample with NiCrAlY coating applied by the $\mathrm{HVOF}$ process and irradiated with the $\mathrm{CO}_{2}$ laser beam, using a scanning speed of $50.00 \mathrm{~mm} / \mathrm{s}$. It is possible to note a homogeneity of the substrate with the coating, with a more regular surface, where it is possible to verify the densification of the previously existing pores. Another parameter observed was that did not happen the displacement of the coating. This indicates that the interaction time between the laser and the material was enough to increase the coating temperature until the melting point.

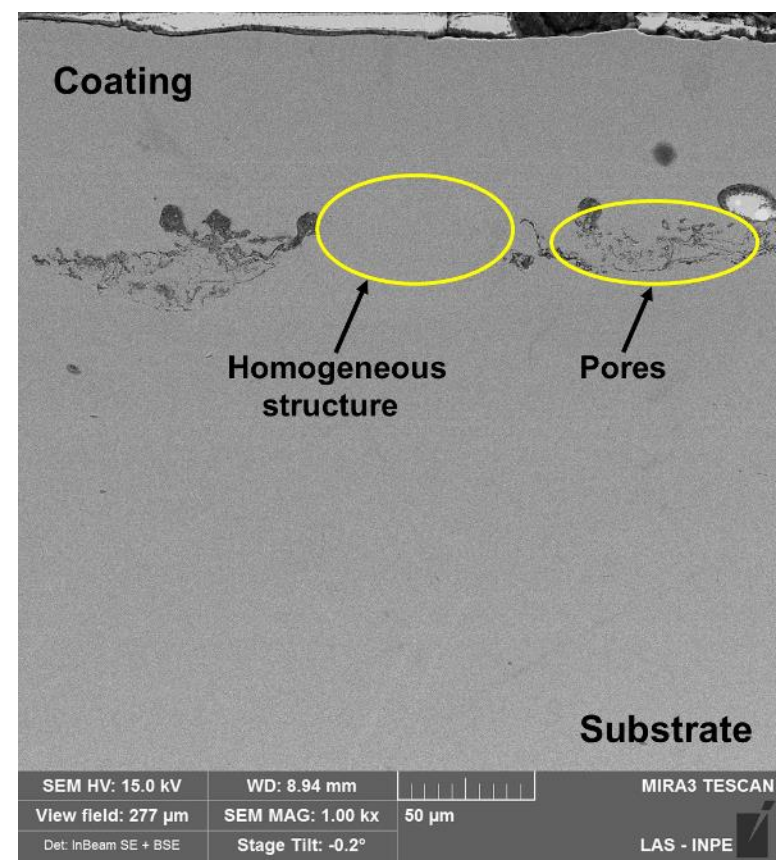

Figure 3: SEM Micrographic of the Cross-section of the NiCrAlY coating on 316 steel deposited by HVOF. 
Semi-quantitative by line scan analysis - EDX was performed in the interface region and also in contours. The Figure 4 shows the graph where it can be noted that the diffusion occurred between the main chemical elements of the substrate and of the NiCrAlY coating. There is an inter-diffusion region of elements like $\mathrm{Fe}$ and $\mathrm{Ni}$, which characterizes the occurrence of the metallurgical bonding mechanism of the order of $20.00 \mu \mathrm{m}$. Ni and $\mathrm{Cr}$ diffused less in Fe than Fe in the NiCrAlY alloy, and one reason for this is that the Fe concentration in the substrate is much higher than the other elements [7].

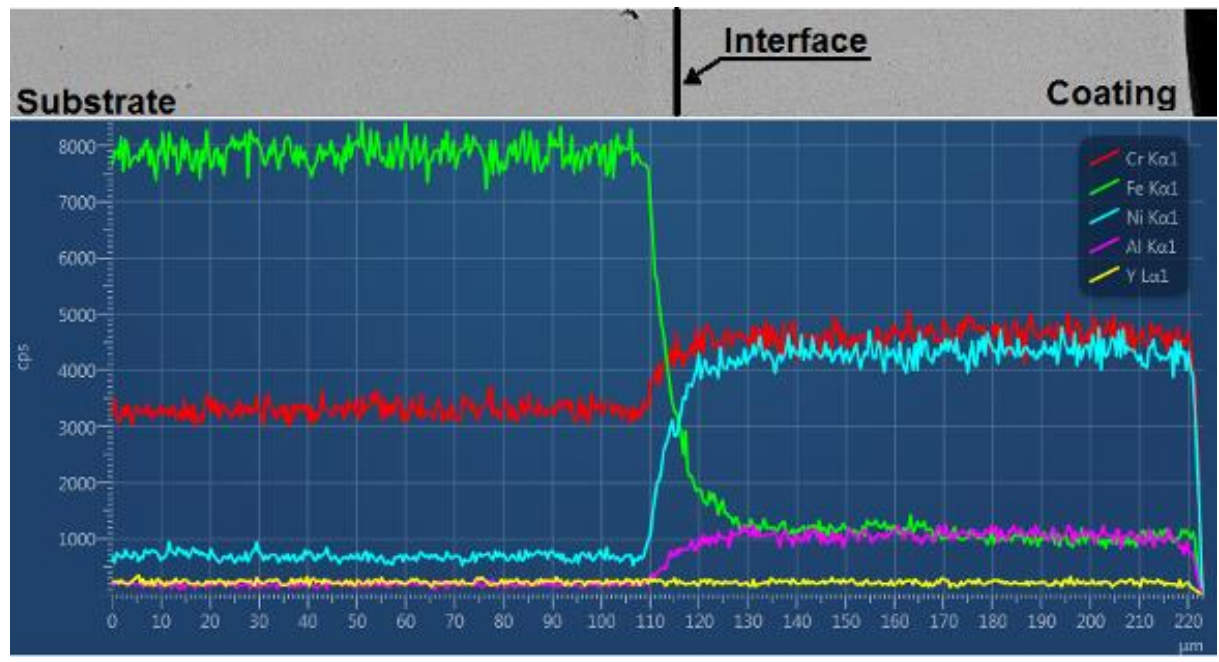

Figure 4: Line scan graph performed by EDS analysis to identify diffusion of NiCrAlY coating materials and 316-steel substrate after $\mathrm{CO}_{2}$ laser irradiation.

The Figure 5 shows the X-ray diffraction of the NiCrAlY powder and the irradiation (performed at a speed of $50.00 \mathrm{~mm} / \mathrm{s}$ ). In the NiCrAlY, the diffractogram shows characteristic peaks of Aluminum (Al) and Nickel (Ni) as presented powder. With the laser irradiation, occurs the appearance of peak of Chromium (Cr), due to the metallurgical connection between the coating and the substrate. Identifying the growth of aluminum oxide $\left(\mathrm{Al}_{2} \mathrm{O}_{3}\right)$ from the high process temperature, this oxide layer is also known as TGO - Thermally Grown Oxide, which aims chemically to protect the substrate. The X-ray diffractogram shows aluminum (Al) and oxygen $(\mathrm{O})$ peaks forming aluminum oxide (Al2O3), which is an indicator of possible oxidation reaction that may have occurred during the laser radiation process. 


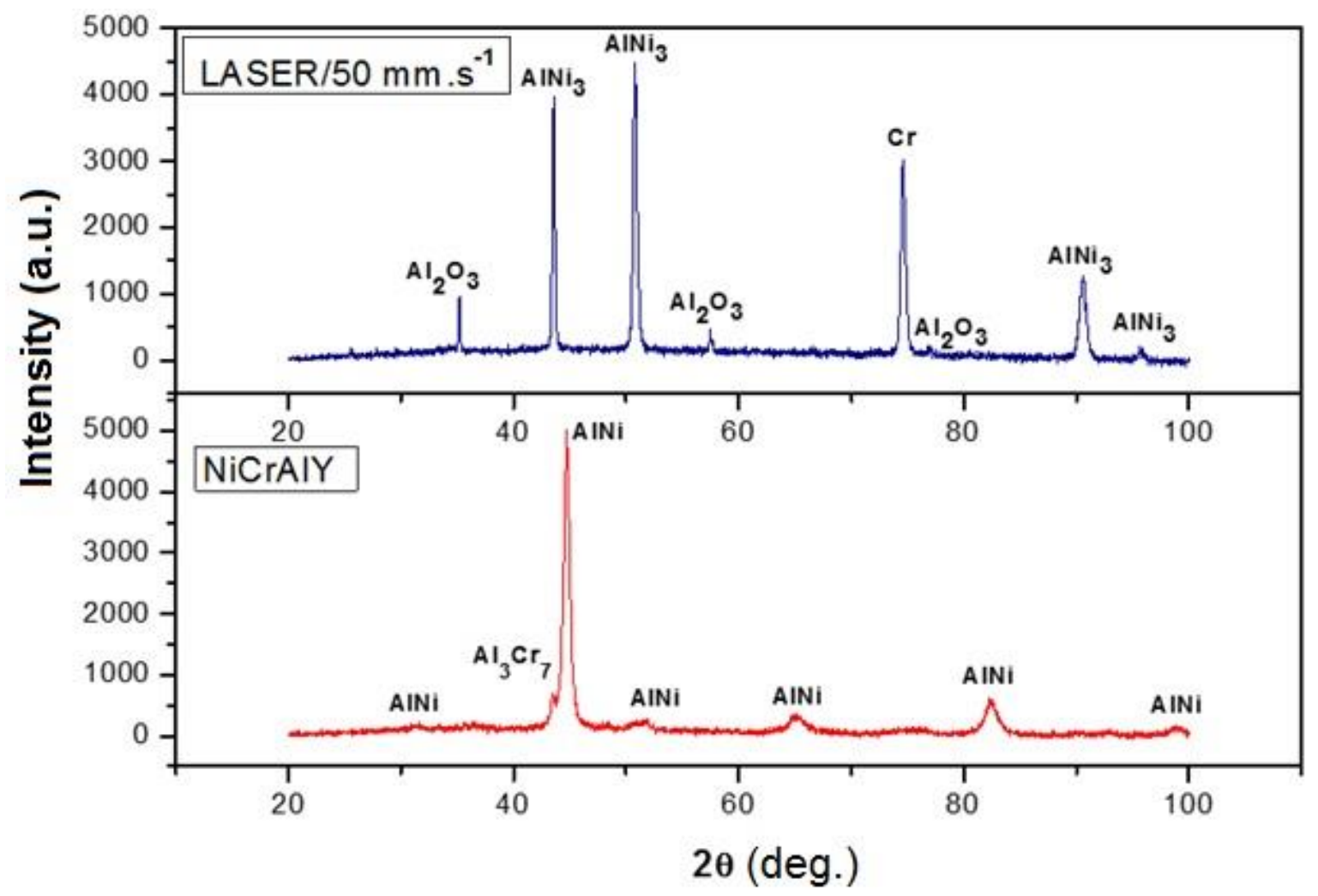

Figure 5: X-ray diffraction of NiCrAlY powder and laser irradiation at a speed of $50.00 \mathrm{~mm} / \mathrm{s}$.

In the X-ray diffraction test aluminum $(\mathrm{Al})$ and oxygen $(\mathrm{O})$ peaks were observed indicating the occurrence of aluminum oxide formation (A12O3). This result shows the formation of oxidation reaction, in other words, the occurrence of metallurgical bonding between the coating and the substrate, as observed by Oliveira et. al. [12], which obtained similar results for the Iconel substrate and coating NiCrAlY irradiated by $\mathrm{CO}_{2}$ laser.

\section{CONCLUSION}

In this study on the metallurgical bonding between substrates and coatings irradiated by laser, it was possible to make the following conclusions:

- The sample irradiated with a scanning speed of $50.00 \mathrm{~mm} / \mathrm{s}$ showed a better densification that one where it was used only the HVOF process;

- Was verified that there is no clear interface be-tween the coating and the substrate and this is a strong indication of the metallurgical bond of these two materials;

- This bond is better when the speed is reduced occurring an increase of energy of this process;

- The graph obtained for line scan by EDX showed that a diffusion occurred between the elements present in the coating and in the substrate, evidencing again the formation of a metallurgical bond.

\section{ACKNOWLEGEMENTS}

The authors want to thank CAPES, Institute for Advanced Studies - IEAv / DCTA and OGRAMAC LTDA.

\section{BIBLIOGRAPHY}

[1] LIMAR, C. R. C., "Thermal Barrier Coatings: Evolution and Perspectives”, The Journal Soldagem \& Inspeção, v. 19, n. 4, pp. 353-363, Dec. 2014.

[2] KALITA, S. J. "Microstructure and corrosion properties of diode laser melted friction stir weld of aluminum alloy 2024 T351”, Applied Surface Science, v. 257, pp. 3985-3997, Feb. 2011. 
[3] HANGONG, W., LIUYING, W., “Thermal spraying application and development trends”, In: Proceedings of the International Thermal Spray Conference \& Exposition: Thermal Spray connects: explore its surfacing potential, Basel, Switzerland, 2-4 May 2005.

[4] PARIONA, M. M., TELEGINSKIA, V., SANTOS, K., et al., "Yb-fiber laser beam effects on the surface modification of Al-Fe aerospace alloy obtaining weld filet structures, low fine porosity and corrosion resistance”, Surface \& Coatings Technology, v. 206, pp. 2293-2301, Jan. 2012 I.

[5] PARIONA, M. M., TELEGINSKIA, V., SANTOS, K., et al., "AFM study of the effects of laser surface remelting on the morphology of Al-Fe aerospace alloys", Materials Characterization, v. 74, pp. 64-76, Dec. 2012 II.

[6] PARIONA, M. M., TELEGINSKIA, V., SANTOS, K., et al., "Influence of laser surface treated on the characterization and corrosion behavior of Al-Fe aerospace alloys", Applied Surface Science, v. 276, pp. 7685, Jul. 2013.

[7] LIMA, C. R. C., TREVISAN, R. E., Thermal Spray: Fundamentals and Applications, 2 ed., São Paulo, Art Liber, 2007.

[8] BERTONI, J. C., PARIONA, M. M., BRINATTI, A. M., et al., "Qualitative identification of phases of a hypoeutectic $\mathrm{Al}$ alloy $1.5 \%$ Fe by weight treated by surface superficial laser refraction by means of X-ray diffraction with angle of incidence", Revista Matéria, v. 20, n. 4, pp. 882-897, Nov. 2015.

[9] PAWLOWSKI, L., The Science and Engineering of Thermal Spray Coatings, 2 ed., New York, John Wiley \& Sons, 1995.

[10] REED, R. C., "The Superalloys Fundamentals and Applications”, 1 ed., New York, Cambridge University Press the Edinburgh Building, 2006.

[11] SHULTZ, U., LEYENS, C., FRITSCHERA, K., et al., "Some recent trends in research and technology of advanced thermal barrier coatings", Aerospace Science and Technology, v. 7, n. 1, pp. 73-80, Jan. 2003.

[12] OLIVEIRA, A. C., DONATO, G., MAGNABOSCO, R., et al., "Analysis of the Metallurgical Bonding between Inconel and NiCrAlY Coatings by HVOF and with $\mathrm{CO}_{2}$ Laser Beam", Materials Science Forum, v. 869, pp. 727-731, 2016.

[13] LAMBARRI, J., LEUNDA, J., NAVAS, V.G., et al., "Microstructural and tensile characterization of Inconel 718 laser coatings for aeronautic components", Optics and Lasers in Engineering, v. 51, n. 1, pp. 813-821, Feb. 2013.

[14] VASCONCELOS, G., et al., "Thermal treatment of the AISI M2 high speed steel promoted by $\mathrm{CO}_{2}$ laser beam", Materials Science Forum, v. 591-593, pp. 62-67, Aug. 2008.

[15] SILVA, C. L., GAMA, L. M., SANTOS, J. A. F., et al., Effect of $\mathrm{La}_{0.8} \mathrm{Sr}_{0.2} \mathrm{MnO}_{3}$ powder addition in the precursor solution on the properties of cathode films deposited by spray pyrolysis, Revista Matéria, v. 22, n. 1, pp. Dec. 2016.

[16] CALLISTER, W. D. J., Materials science and engineering: an introduction, 6 ed., London, John Wiley \& Sons Inc., 2002.

\section{ORCID}

Silvelene Alessandra da Silva Renê Martins Volu

Paulo Paiva Oliveira Leite Dyer Ana Claudia Costa de Oliveira Getúlio de Vasconcelos https://orcid.org/0000-0003-1601-5373

https://orcid.org/0000-0002-7968-1034

https://orcid.org/0000-0001-7110-6871

https://orcid.org/0000-0002-2437-8425

https://orcid.org/0000-0002-2943-0915 